\author{
Mikołaj Smykowski \\ Instytut Etnologii i Antropologii Kulturowej \\ Wydział Historyczny \\ Uniwersytet im. Adama Mickiewicza w Poznaniu
}

\title{
Niematerialne, ale czy dziedzictwo? Tradycje wynalezione w Połajewie (powiat czarnkowsko-trzcianecki) i ich popularyzacja na gruncie społeczności lokalnej
}

\begin{abstract}
Streszczenie: Celem artykułu jest szczegółowy etnograficzny opis dwóch wybranych przykładów niematerialnego dziedzictwa kulturowego, odnotowanych w trakcie badań terenowych prowadzonych w ramach projektu Atlas niematerialnego dziedzictwa kulturowego wsi wielkopolskiej na terenie gminy Połajewo (powiat czarnkowsko-trzcianecki). Pierwszym z nich jest zwyczaj dorocznych spotkań kobiet 8 marca, podczas tak zwanego Sabatu Ciot Połajewskich; drugim cykliczne spotkania w Połajewie kolędników-dudziarzy, w drugą niedzielę stycznia. Oba zwyczaje, mimo iż są przedłużeniami lokalnych tradycji zapisanych w przekazach oficjalnych (tryptyk Pokłon Pasterzy, od którego wywodzić ma się tradycja gry na dudach) oraz ustnych (legendy dotyczące obecności w gminie czarownic), w aktualnej formie funkcjonują względnie od niedawna. Głównym problemem towarzyszącym ich opisowi jest postawienie pytania, na ile są one związane z tradycyjnie pojmowanym niematerialnym dziedzictwem kulturowym, na ile zaś stanowią pewne novum kulturowe, wynalezione (invented) przez animatorów w celach ożywienia partycypacji w kulturze lokalnej? Poszukując odpowiedzi na to pytanie, w części analitycznej artykułu odwołuję się do koncepcji tradycji Erica Hobsbawma oraz Jerzego Szackiego.
\end{abstract}

Słowa kluczowe: tradycja, tradycja wynaleziona, kulturowe dziedzictwo niematerialne, Połajewo

\section{Intangible, but Is It Still a Heritage? Invented Traditions \\ in Połajewo (Czarnków-Trzcianka district) \\ and Their Popularization among the Local Community}

\begin{abstract}
The aim of the article is to provide a detailed ethnographic description of two significant examples of intangible cultural heritage researched during the realization of the fieldwork project Atlas niematerialnego dziedzictwa kulturowego
\end{abstract}


wsi wielkopolskiej (Intangible Cultural Heritage Atlas of Greater Poland Village). The first one is a custom of annual women's meetings on 8 March during the so-called Sabat Ciot Połajewskich [literally: the Sabbath of Połajowo Aunts], the second one is a local festival of pipers that takes place in Połajewo on 2 January. Despite the fact that they are in a way extensions of old-time local traditions, in their present form both of them have been practised for a relatively short while. The main problem of the article is to find an answer to the crucial question - are they still phenomena belonging to the traditionally understood intangible cultural heritage or rather should be considered a cultural invention introduced by animators to revive the participation in local culture. The analysis is provided in terms of the conceptions of tradition proposed by Jerzy Szacki and Eric Hobsbawm.

Key words: tradition, invented tradition, intangible heritage, Połajewo

Celem artykułu jest przyjrzenie się dwóm zjawiskom kulturowym - Sabatom Ciot Połajewskich oraz dorocznym spotkaniom kolędników-dudziarzy w Połajewie - zarejestrowanym i zbadanym podczas etnograficznych badań terenowych Atlas niematerialnego dziedzictwa kulturowego wsi wielkopolskiej, prowadzonych przeze mnie na zlecenie Muzeum Narodowego Rolnictwa i Przemysłu Rolno-Spożywczego w Szreniawie na terenie powiatu czarnkowsko-trzcianeckiego ${ }^{1}$. Ich szczegółowy opis oraz dalsze rozważania teoretyczne poświęcone będą sposobom, w jakie wyeksploatowane treści kulturowe, stanowiące oś tradycyjnego przekazu międzygeneracyjnego, zastępowane są przez nowe (do tej pory drugoplanowe) figury oraz jak zmienia się myślenie o lokalnej tradycji i jej aktualne praktykowanie. Uważam bowiem, że w wyszukiwaniu i odzyskiwaniu nieoczywistych znaczeń, zawierających się w dawnych i powszechnie znanych wytworach lokalnej kultury, objawia się jej dynamika, będąca odzwierciedleniem aktualnych potrzeb społecznych. W artykule posłużę się terminem „tradycja wynaleziona”, zaproponowanym przez Erica

1 Projekt Atlas niematerialnego dziedzictwa kulturowego wsi wielkopolskiej finansowany przez Ministerstwo Nauki i Szkolnictwa Wyższego (Narodowy Program Rozwoju Humanistyki; 11H/11/026580) realizowany był w latach 2012-2015 na terenie siedmiu powiatów Wielkopolski. W powiecie czarnkowsko-trzcianeckim badania etnograficzne prowadzono w gminach Czarnków, Drawsko, Krzyż Wielkopolski, Lubasz, Połajewo, Trzcianka oraz Wieleń. Łącznie przeprowadzono 227 wywiadów w 103 wsiach powiatu. 
Hobsbawma [2008], by odpowiedzieć na pytania: czy możliwa jest koegzystencja zwyczajów dawnych i nowych oraz czy te drugie są zagrożeniem dla tych pierwszych? Na czym zasadza się atrakcyjność połajewskich tradycji wynalezionych oraz co sprawia, że ich praktykowanie staje się nie tylko nieodłącznym elementem kalendarza lokalnych świąt, ale również wizytówką wpływającą na zewnętrzny obraz gminy jako dbającej o swoje (rzekome lub postulowane) kulturowe dziedzictwo?

Rozważania w pierwszej kolejności poświęcę etnograficznemu opisowi rozpatrywanych tu zjawisk, które można by określić mianem tradycji wynalezionych. Opis ten w dużej mierze bazować będzie na materiale empirycznym - wypowiedziach mieszkańców Połajewa zarejestrowanych w trakcie badań ${ }^{2}$. Celem takiego zabiegu będzie przedstawienie recepcji lokalnych treści kulturowych (tradycja przedmiotowa; dziedzictwo, przede wszystkim niematerialne), stosunku do nich (tradycja podmiotowa) oraz procesu ich reinterpretacji i przetwarzania (transmisja społeczna i kulturowa) [Szacki 2011].

\section{Tryptyk z Połajewa, czyli tradycja odnaleziona}

Przy bocznym ołtarzu kościoła pod wezwaniem św. Michała Archanioła w Połajewie znajduje się renesansowy tryptyk autorstwa Mateusza Kossiora zatytułowany Pokłon Pasterzy, wykonany techniką olejną w 1572 roku. Przekazy ustne głoszą, że w czasach najazdu Turków na Europę był on obrazem polowym Jana III Sobieskiego, który podobno miał się do niego modlić podczas oblężenia Wiednia w 1683 roku. Bardziej prawdopodobną wersję opisuje Bogdan Garstecki, lokalny historyk, autor zbioru podań oraz legend z Połajewa i okolic:

[...] jeśli mowa o tych legendach to niektórzy ludzie tak wspominają i ciut w tym prawdy może być, bo jeszcze ojcowie wspominali, że najstarszy obraz w naszym kościele, tryptyk Kossiora Mateusza, że to był jako ołtarz polowy króla Sobieskiego pod Wiedniem. Może to być prawda, ale nie Sobieskiego. Ja tak dochodziłem i znalazłem w Internecie życiorys naszego

2 Wywiady znajdują się w archiwum projektu Atlas niematerialnego dziedzictwa kulturowego wsi wielkopolskiej. Łącznie zarejestrowano 24 wywiady. 
dziedzica. Po Czarnkowskich kupili to Miączyńscy - Atanazy Miączyński był bliskim przyjacielem Sobieskiego, nawet życie mu uratował w bitwie pod Wiedniem. Był z nim razem tam też, jest nawet na obrazie Jana Matejki, stoi tam w takiej czamarze [szesnastowieczny męski kożuch - M.S.], tam Miączyński jest, nasz właściciel, więc mógł on mieć ten ołtarz. Był tu właścicielem i ofiarował go do kościoła po tej bitwie, tak mogło być, tak przypuszczam ja [PO_PO_08] $]^{3}$.

Centralna część tryptyku przedstawia scenę Narodzenia Pańskiego wraz z adorującymi Jezusa świętymi, aniołami i pielgrzymami. Kiedy w 1994 roku, po gruntownej renowacji obrazu w Muzeum Narodowym w Poznaniu, okazało się, że w prawym dolnym rogu skrywa on kolędującego przy żłobie Jezusa pasterza grającego na dudach, obrazem żywo zainteresował się Janusz Jaskulski, kustosz Muzeum Instrumentów Muzycznych w Poznaniu, a także pracownik poznańskiego Centrum Kultury Zamek i instruktor Kapeli Dudziarzy Wielkopolskich - Romuald Jędraszak, który postanowił założyć w Połajewie nowy zespół, przekazując technikę grania na dudach młodym połajewianom.

W ten sposób odkrycie jednego z najstarszych zachowanych w Polsce wizerunków dudziarza przyczyniło się do zawiązania się w 2001 roku Młodzieżowej Kapeli Dudziarskiej, odbywającej odtąd cotygodniowe próby w Gminnym Ośrodku Kultury w Połajewie. Warsztaty prowadzone są pod kierownictwem Romualda Jędraszaka, który, tak jak niegdyś jego mistrz - Stanisław Grocholski, uczy gry na dudach metodą tradycyjną ze słuchu. Do zespołu w listopadzie 2012 roku należało trzech dudziarzy (dudy wielkopolskie) i cztery skrzypaczki (skrzypce podwiązane) ${ }^{4}$. Skład kapeli

3 Kody w nawiasach kwadratowych są odnośnikami do wywiadów, z których pochodzą cytaty wykorzystane w artykule. Sposób kodowania: GMINA_WIEŚ_NUMER.WYWIADU. Na terenie gminy Połajewo badania prowadzono w następujących miejscowościach: Boruszyn (PO_BO); Krosin (PO_KN); Krosinek (PO_KK); Młynkowo (PO_MŁ); Połajewo (PO_PO); Przybychowo (PO_PRZ); Sierakówko (PO_SI).

4 Więcej na temat charakterystyki i specyfikacji wielkopolskich ludowych instrumentów muzycznych znaleźć można w rozdziale Instrumenty muzyczne autorstwa D. i A. Pawlaków zamieszczonym w tomie 3 Kultury Ludowej Wielkopolski pod redakcją J. Burszty [Pawlak, Pawlak 1967: 269-298]. 
zmienia się dynamicznie, bowiem uzależniony jest od liczby chętnych do nauki gry na dudach. Jak wspomina kierowniczka GOk-u:

No to nie jest aż tak dużo, bo to jest sześć czy siedem osób, bo to skrzypki i dudy tylko i wyłącznie, bo to jest ze słuchu grane, tam nie ma żadnych nut. A dudy niestety są drogim instrumentem. Już jest nabór drugi czy trzeci nawet. Tak jakoś jest [...]. My tu mamy dwójkę w zasadzie takich, co są od początku. Jedna dziewczyna, jeden chłopak, gdzie już studiują, mają pracę i przychodzą na próbę [PO_PO_06].

Zespół dudziarzy z Połajewa podejmuje stałą współpracę i koncertuje wraz z kapelami z Polski (Kapela Koźlarska „Świecary”, Kapela Dudziarska „Manugi”, Kapela Dudziarska „Koźlary”, Kapela Dudziarzy Wielkopolskich CK „Zamek” Poznań, Młodzieżowa Kapela Dudziarska Zespołu Folklorystycznego „Szamotuły”, Młodzieżowa Kapela Dudziarska z Gołębina Starego), Słowacji (Zespół z Podpoljania Lubomira „Tatarki”, Kapela Gajdoszy „Beskyd”, Kapela Gajdoszy „Tal’Agovci”), Czech („Rodzina Reżnych”) oraz Belgii (Kapela Dudziarzy „Musa”). Połajewianie biorą też udział w festiwalach muzyki dudziarskiej, między innymi w słynnym Pipefest w Edynburgu w 2010 i 2011 roku, a ponadto w Muzeum Chleba w Jaraczu, na XXV Konkursie Kapel Dudziarskich w Bukówcu Górnym, X Konfrontacjach Kapel Dudziarskich w Poznaniu oraz uczestniczyli w konkursach: Konkursie Muzyki Ludowej w Kopanicy i konkursie „Stara Tradycja 2012”.

Od 2000 roku w Połajewie organizowane są w trzecią niedzielę stycznia Spotkania Kolędników „Do szopy hej pasterze-dudziarze!”. W trakcie piętnastu edycji (ostatnia odbyła się 18 stycznia 2015 roku), ten początkowo niewielki lokalny festiwal wyewoluował do rangi wydarzenia o charakterze międzynarodowym, na które co roku przyjeżdżają wspomniane kapele dudziarskie z Polski i z zagranicy. Program wydarzenia obejmuje zazwyczaj kilka istotnych punktów ${ }^{5}$. Spotkania kolędników otwiera uroczysty przemarsz spod Gminnego Ośrodka Kultury w Połajewie pod kościół pod

5 Szczegółowe harmonogramy poszczególnych spotkań dudziarskich oraz bogata galeria zdjęć i filmów ze wszystkich edycji festiwalu dostępne są na stronie internetowej gminy Połajewo: http://www.polajewo.pl. 
wezwaniem św. Michała Archanioła, gdzie następnie odprawiana jest Msza Pasterska. Po nabożeństwie wszystkie zaproszone zespoły spotykają się na wspólnym kolędowaniu pod tryptykiem Pokłon Pasterzy. Po powrocie z kościoła odbywa się oficjalna gala, której przewodniczą przedstawiciele lokalnych władz: starosta powiatu czarnkowsko-trzcianeckiego, wójt gminy Połajewo oraz organizatorzy wydarzenia. Zwieńczeniem gali są występy kapel dudziarskich oraz towarzyszących im zespołów artystycznych z okolicznych miejscowości.

Idea wspólnego kolędowania podczas spotkań dudziarskich spotyka się w całej gminie z bardzo dobrym odbiorem społecznym. Z roku na rok przybywa słuchaczy, a połajewski zespół zapraszany jest na różnego rodzaju uroczystości lokalne: dożynki, festyny, odpusty, jubileusze pożycia małżeńskiego [Rybarczyk 2013: 71]. Popularność Młodzieżowej Kapeli Dudziarzy sprawiła, że obecnie ich działalność jest jednym z najbardziej rozpoznawalnych przejawów kultury „tradycyjnej” w gminie, o czym dobitnie świadczą pełne dumy wypowiedzi jej mieszkańców. W 2012 roku Fundacja Rozwoju Demokracji Lokalnej wyróżniła inicjatywę styczniowych spotkań dudziarskich, doceniając jej założenia, czyli powrót do starych zwyczajów kolędowania poprzez ożywienie sceny Bożego Narodzenia z zabytkowego tryptyku [Rybarczyk 2013: 72].

"Co nowego powstało, i oby przetrwało, to na pewno dudziarze - kapela dudziarska - bo tego nie było tu nigdy" [PO_PO_08] - wspomniał w jednej z rozmów Bogdan Garstecki, potwierdzając wynalezienie tradycji grania na dudach w Połajewie i wyrażając jednocześnie chęć jej podtrzymania. Ten paradoks zdaje się być cechą nierozerwalnie związaną z wieloma nowymi zjawiskami, które pretendują do miana tradycji, odnosząc się do przeszłości jedynie powierzchownie. Eric Hobsbawm pisze, że „ich osobliwość - o ile odwołują się w jakiś sposób do historii - polega na tym, że ich związek z przeszłością jest sztucznie wytwarzany" [Hobsbawm 2008: 10]. Warto zastanowić się, czy jest tak również w przypadku dudziarzy w Połajewie i co dokładnie w tym kontekście znaczy „wynajdywanie”. Etymologia tego słowa skłania do jego dwojakiego rozumienia. Z jednej 
strony czasownik wynajdywać (ang. inventing) może znaczyć tyle, co odkrywać (wymyślać coś nowego lub odnajdywać coś, co pozostawało w ukryciu). Z drugiej zaś strony, potoczne jego rozumienie konotuje skojarzenia z „doszukiwaniem się" (z czynnością wykonywaną celowo, nierzadko „na siłę”). Jakkolwiek trudne będzie ustalenie, które z powyższych znaczeń przyświecało (świadomie lub nie) wynalazcom zwyczaju grywania na dudach, warto ustalić, w jakim stopniu to, co zostało wynalezione jest przedłużeniem bądź zerwaniem z tradycją (w sensie przedmiotowym, czyli dziedzictwem).

Pretekstem do rozpoczęcia działalności Młodzieżowej Kapeli Dudziarskiej i zainicjowania cyklu spotkań kolędniczych stało się (niespodziewane?, przypadkowe?) odkrycie. Materialny nośnik kulturowy, element lokalnego dziedzictwa - w tym przypadku obraz - okazał się impulsem do wytworzenia nowego rodzaju jakości; przeniesienia tego, co przedstawił autor tryptyku Pokłon Pasterzy w świat rzeczywisty - przełożenia danych ikonograficznych na praktykę społeczną, niezależnie od tego, czy wyrażona przez malarza sytuacja miała jakiekolwiek potwierdzenie historyczne lub etnograficzne ${ }^{6}$. Pasterz-dudziarz, będący zaledwie jednym z elementów warstwy ikonicznej obrazu jako spójnej, zamkniętej formy, otrzymał nowe znaczenie; na tyle, jak się okazuje, sprawcze, że stał się symbolem i protoplastą trwającego piętnaście lat festiwalu. Fragment malowidła, poprzez celowy zabieg jego wyłączenia i przypisania mu instrumentalnego znaczenia, stał się pars pro toto całości, jaką współtworzył. W tym kontekście trudno nie zgodzić się z Hobsbawmem, że bazą wynajdywania tradycji ,jest wykorzystywanie starych materiałów do budowania wymyślonych tradycji nowego typu w imię całkowicie nowych celów" [Hobsbawm 2008: 14]. Można by w tym miejscu zapytać, czy nie jest czasem tak, że tryptyk w Połajewie nie kojarzy się już okolicznym mieszkańcom z zabytkowym dziełem sztuki lub świętym obrazem, tylko z tym, że widnieje na nim pasterz-dudziarz? Aby odpowiedzieć na to pytanie, trzeba by oczywiście przeprowadzić osobne szczegółowe badania.

6 Mam tutaj na myśli fakt obecności dud jako instrumentu charakterystycznego dla tej części Wielkopolski, nie zaś potwierdzenie faktu obecności dudziarza podczas Narodzenia Pańskiego. 
Istotą wyrażonych wyżej wątpliwości jest jednak uzyskanie odpowiedzi na pytanie zgoła inne: co sprawiło, że zwyczaj grania na dudach stał się tak atrakcyjny, że zasymilował się z połajewską tkanką kulturową tak dobrze?

Najprawdopodobniej, zaszczepiony, zresztą z zewnątrz, zwyczaj kolędowania przy akompaniamencie dud, trafił na bardzo podatny grunt - dotychczasowa wiedza na temat rzeczonego tryptyku, umiejscowionego w lokalnym kościele parafialnym nieco na uboczu, w lewej nawie, pozostawała uśpiona. Owszem, obraz istniał jako element lokalnego dziedzictwa kulturowego, nie stanowił jednak osi, wokół której kształtowały się współczesne zjawiska kulturowe. Dopiero wraz z jego renowacją, rewitalizacją objęta została również jego warstwa symboliczna, na tyle nośna, by przy pomocy działań animacyjnych dostała się do zbiorowej świadomości mieszkańców Połajewa.

\section{Sabat Ciot Połajewskich, czyli tradycja oswojona}

Legenda dotycząca ciot połajewskich ${ }^{7}$ opisywana była do tej pory w różnych zestawieniach podań i legend ludowych doliny nadnoteckiej [Łysiak 1992; Garstecki 2010]. Najbardziej prawdopodobna wersja jej powstania odnosi się do czasów zaboru niemieckiego, kiedy to na tak zwanych Górach - najstarszej części Połajewa położonej na wzniesieniu - w pobliżu wiatraka wchodzącego w skład gospodarstwa Niemca Torny, miały straszyć nocami, ukryte wśród zadrzewień, czarownice. Wiatrak zdaniem Bogdana Garsteckiego pracował jeszcze w czasach drugiej wojny światowej, przypuszczalnie do momentu wysiedlenia gospodarza Torny [Garstecki 2010: 241]. Najwyższe wzniesienie w Połajewie, do dzisiaj nazywane

7 W tomie 3 Kultury ludowej Wielkopolski Zbigniew Jasiewicz zauważa, że nazwa ciota (jako synonim słowa czarownica) spotykana jest jedynie w Wielkopolsce i na niektórych terenach z nią sąsiadujących [Jasiewicz 1967: 466]. Jakkolwiek powstanie samej nazwy nie jest jasne, Jasiewicz wskazuje na jej bezpośredni związek z zaangażowaniem w praktyki magiczne starszych, niezamężnych kobiet uboższego stanu określanych mianem ciotek [Jasiewicz 1967: 467]. Obecnie funkcjonujące określenie nie odnosi się jednak ani do statusu materialnego, ani do stanu cywilnego kobiet odtwarzających zwyczaje związane z połajewskimi ciotami; wskazuje jedynie na przedłużenie funkcjonowania w języku potocznym słowa ugruntowanego już w lokalnym folklorze. 
Tornową Górką, stało się wedle przekazów ustnych mieszkańców nie tyle miejscem odbywania się sabatów, co stałym siedliskiem ciot.

Bliska obecność ciot wywoływała wśród mieszkańców Połajewa obawę, dostarczając jednocześnie w miarę racjonalnego wytłumaczenia, kiedy w pobliżu gospodarstwa czy domu wydarzało się coś niespodziewanego lub niedobrego w swoich skutkach. Zazwyczaj winę za tego typu zdarzenia przypisywano czarownicom, które nie wprost, a pod przykrywką kamuflażu z czarów, lubowały się w rzucaniu uroków. Tak zrodziły się w Połajewie przesądy dotyczące różnych sfer codziennego życia oraz praktyk zapobiegania bądź przeciwdziałania skutkom uroków. W sytuacji, kiedy nie wie się dokładnie, która z kobiet we wsi jest ciotą, szczególnie unika się krzywych i zazdrosnych spojrzeń sąsiadek, mających skutkować celowym zauroczeniem. Młode matki nie pokazują swoich niemowląt do momentu chrztu, nie wieszają także pieluch na sznurach do prania zawieszonych w obejściu, by nie dawać sygnału ciotom o tym, że w domu pojawiło się dziecko - „każdy, kto wierzy w to naprawdę, ma swoje sposoby, by przeszkodzić zauroczeniu i wie, jak mu zaradzić" [Garstecki 2010: 241]. Do dzisiaj pamięta się zresztą o dwóch najpowszechniejszych sposobach zdejmowania uroków z dzieci. Pierwszym nich jest pozbycie się słonego potu, który jest pierwszym objawem „ociotowania”:

Trzeba tam magiczne wręcz okultystyczne jakieś tam czynności wykonać, ale z drugiej strony może spowodować, że to dziecko będzie płakało dalszą część dnia i one właśnie bardzo często są związane z dziećmi nie wiem czemu [...]. Trzeba polizać czoło, kształt krzyża na czole [wykonać - przyp. M.S.] i wtedy podobno [można - przyp. M.S.] poczuć, że czoło ma ten słony smak złego uroku rzuconego i wtedy to matka zlizuje [PO_PO_05-06].

Drugi sposób polega na odczynieniu uroku w trakcie kąpieli z dodatkiem ostrożnia [łac. cirsium oleraceum], potocznie nazywanego czarcim żebrem $^{8}:$ „[...] u nas matki, które mają dzieci tak zwane ociotowane, kąpią

8 Na temat roślin uznawanych przez lokalne społeczności wiejskie za posiadające właściwości lecznicze i odczyniające uroki, przeczytać można w artykule Anny Drożdż Kołysanie Diabła - zwyczaje wierzeniowe jako przykład niematerialnego dziedzictwa kulturowego [2013]. 
je w czarcim żebrze i wylewają na skrzyżowaniu. Drogi nie muszą się dokładnie przecinać, ale jedna musi wpadać do drugiej. I wylewasz tę wodę z umycia” [PO_BO_25-26]. „Moja znajoma musiała się kąpać trzy dni, jest takie zioło, to się nazywa czarcie żebro. Już na pierwszy dzień było dużo takiej brudnej piany [...] i przeszło. Wszystko zależy od tego czy w to wierzysz. Bo jak w to wierzysz, to ci pomoże, nieważne, czy to jest czarcia woda, czy święcona woda" [PO_PRZ_33-34].

Najpowszechniejszym natomiast działaniem apotropeicznym było, a bywa tak również do dzisiaj, przywiązywanie do wózków dziecięcych czerwonych wstążek, mających odwracać uwagę czarownic od dziecka jaskrawością koloru tak, by pierwsze, pełne złego uroku ciotowskie spojrzenie padło właśnie na wstążkę, nie zaś na dziecko: „Ta czerwona wstążeczka przy wózeczku to też tu było, chociaż teraz tego się nie spotyka, może tam babcie jeszcze coś tam, ale to się kończy” [PO_PO_08]. „No kiedyś mówili, żeby przed chrztem nie wyjeżdżać z dzieckiem na ulicę, ale teraz to już nie ma tego. Ale wstążeczki to nie raz przypną!" [PO_MŁ_01].

Żywotność legendy, a także zawartych w niej praktyk kulturowych, występujących również współcześnie, potwierdzają autochtoniczni mieszkańcy Połajewa i pobliskich miejscowości: „To funkcjonowało w środowisku, wśród znajomych, kolegów, gdzieś tam. Jak to przekaz, jak to legenda, zawsze się usłyszy coś, nie że ktoś tam usiadł i opowiedział o tym tylko to żyje razem z tym jak ja wzrastałam w tym środowisku" [PO_PO_05-06]. „Czarownice u nas były. Jak się urodziłam, to te czarownice były, to mówią, że cioty połajewskie! I że są do dziś, ale ja jeszcze nie widziałam żadnej!" [PO_PO_10]. „Zawsze [...] straszyli ciotami połajewskimi. Znaczy, jako że ja w tej części Połajewa mieszkałam, nie chodziliśmy na Góry, ja się tam normalnie dopiero jako osoba dorosła rozpatrzyłam" [PO_PO_09].

Wierzenia w czarownice i rzucane przez nie uroki były i są do dzisiaj żywotne w środowiskach wiejskich północno-zachodniej Wielkopolski [Zadrożyńska 1985, 2002; Łysiak 1992]. W wielu relacjach terenowych podkreślany jest ambiwalentny charakter ich ukrytej obecności - warto zauważyć, że ciotom przypisywano niegdyś nie tylko moc czynienia uroków, ale również zdolności wynikające ze znajomości ludowej medycyny i ziołolecznictwa. Fach ten, kulturowo przypisywany jest właśnie kobietom 
- wiejskim „babom” - odbierającym porody, asystującym w trakcie ostatniej posługi, pośredniczącym między światami ludzi i nie-ludzi, żywych i umarłych [Zadrożyńska 2002: 42]. O tym, że cioty mieszkające w Połajewie nie zawsze uchodziły za złe, wspomina jedna z mieszkanek:

To jest takie właśnie na granicy [...] bardzo się wczytałam w Annę Zadrożyńską [...] ta ciota i tamte czarownice, wiedźmy są ujęte, jako takie osoby pomiędzy światami - pomiędzy światem realnym, a tym magicznym. One tam często odbierają porody, są akuszerkami, czyli pomagają człowiekowi przyjść na ten świat, także ludzie się z nimi bardzo liczą, bo one coś więcej wiedzą o tym świecie, może co tam jest po drugiej stronie? A jednocześnie trochę się ich boją, bo ta ciota może coś zrobić dobrego, czyli zna dużo tych obrzędów jak wyleczyć dziecko, jak jest chore [PO_PO_05-06].

Jest to jeden z prawdopodobnych powodów oswojenia postaci cioty i próby odczynienia jej upiornego wizerunku. Drugim z nich może być rozpoznawalność połajewskich ciot poza administracyjnymi, a także etnograficznymi granicami gminy Połajewo. Wskazywać na to mogą fragmenty wypowiedzi zarejestrowane $\mathrm{w}$ trakcie badań:

[...] tutaj w Obornikach Wielkopolskich, jak jedziemy do Poznania, to nie jest daleko i możliwe, że jakaś tam ludność napływowa, to może to takie dziwne nie było, jak ktoś mówił, że z Połajewa to tam, gdzie są te cioty. Natomiast jak już trafiłam do Poznania na studia i pojawiła się dziewczyna gdzieś tam spod Olsztyna, i ona mówi, a Połajewo, to tam, gdzie są te cioty, to już tam zaczęło coś, tam w głowie świtać, bo te cioty, to nie jest taki tylko zwykły wymysł. No i ta ciota jest tutaj chyba od pokoleń. Te cioty, to jest taki stały element tutaj krajobrazu naszego [PO_PO_05-06].

Jak kiedyś kupowałam bilet do Połajewa, jak wracałam z Poznania, to sprzedawca mówi: tam gdzie są te cioty połajewskie?! [PO_PO_10].

Zgodnie z cytowanymi wypowiedziami, potoczne czy też zwyczajowe określenie połajewian (używane zarówno przez mieszkańców innych miejscowości w gminie, jak i przyjezdnych lub obcych) utrwaliło status 
znaczenia terminu ciota połajewska jako charakterystycznego dla regionu egzoetnonimu. Jak wskazuje Miłosława Nowicka-Mazur - pomysłodawczyni współczesnych Sabatów Ciot Połajewskich - ugruntowanie się skojarzenia z ciotami należało wykorzystać na polu aktywizacji społeczności lokalnej oraz promocji miejscowości, poprzez wykorzystanie specyficznych dla niej zwyczajów: „W różnych okolicznościach, w różnych środowiskach obracałam się i bardzo często spotkałam się z tym, że ludzie kojarzą taki termin ciota połajewska, że to jest swego rodzaju marka, którą trzeba opracować" [PO_PO_05-06]. Dlatego też w 2010 roku, z okazji Dnia Kobiet, Gminny Ośrodek Kultury zorganizował pierwszy Sabat Ciot Połajewskich, który od tej pory odbywa się w Połajewie cyklicznie. Przebieg wydarzenia co roku wygląda podobnie, zazwyczaj rozpoczyna się uroczystą odprawą korowodu ciot przybyłych pod Gminny Ośrodek Kultury w Połajewie. Po łyku magicznej mikstury „na odwagę, wspólnych zdjęciach na miotłach (wykonanych przez jednego z połajewskich twórców ludowych) i wywiadach dla lokalnej telewizji, korowód rusza w rytm muzyki, w asyście członków Ochotniczej Straży Pożarnej. Pochód odbywa się wzdłuż głównej ulicy miejscowości, w kierunku Tornowej Górki - pierwotnej siedziby ciot - a towarzyszą mu tańce z miotłami i śpiewy „na ciotowską nutę”. Jak wspominają uczestniczki parada jest tak widowiskowa, a zarazem pozbawiona znamion okultyzmu czy elementów czarnej magii, że nawet lokalny proboszcz nie ma nic przeciwko niej. Po dojściu na Tornową Górkę, cioty zbierają się w krąg i jednogłośnie deklamują tekst dowcipnej przysięgi:

Dobrą ciotą być ślubuję,

Cnót ciotowskich dochowuję.

Straszyć będę kogo da się,

Swym ciotowstwem w pełnej krasie.

Magii, legend pilnie strzec,

Bo to jest ciotowska rzecz.

Dziś przyrzekam już nie straszyć,

Dziatek w wózkach z gminy naszej.

Innych kobiet ciotowanie,

Niech się innych celem stanie.

Gdy zawiodę inne cioty, 
Niech mnie prędzej zjedzą koty.

A gdy wzbudzać będę zbędne waśnie,

Niech w mą miotłę piorun trzaśnie.

I w asyście ciot sąsiadek, miotłą mnie walnijcie w zadek

[tekst ślubowania z roku 2010].

Jej wypowiedzenie skutkuje utrwaleniem statusu cioty i dotyczy to zarówno kobiet o ugruntowanej pozycji w społeczności ciot połajewskich, jak i ciot-nowicjuszek. Jest to kulminacyjny punkt imprezy, która następnie przenosi się do Ośrodka Kultury, gdzie cioty wraz z osobami towarzyszącymi biesiadują, układając ciotowskie zawołania: „Na połajewską ciotę każdy ma ochotę!”; „Ciota swoją miotłę ma i na nosie wszystkim gra!”; „Chcesz być ciotą - żyj z ochotą!”; „Gdy cioty po wsi latają, to chłopy pod stoły się chowają".

Wiosenne sabaty czarownic, podobnie jak spotkania dudziarzy, są jednym z kluczowych wydarzeń w dorocznym kalendarzu kulturalnym mieszkańców Połajewa. Cztery dotychczasowe edycje doczekały się nie tylko zwolenników wśród lokalnej społeczności, ale wzbudziły również zainteresowanie mediów ${ }^{9}$. W 2014 roku Sabat Ciot Połajewskich odbywał się (co prawda w nieco zmienionej formie, bowiem towarzyszył świętu powitania wiosny) pod auspicjami Roku Kolberga ${ }^{10}$.

„[...] po co wymyślać tradycję nową, skoro już funkcjonuje. Tak jak dudziarze. Jest na obrazie jakiś ślad tego, mamy już coś swojego, mamy już jakieś dziedzictwo i do tego można coś tam ożywić, nadbudować i fajnie to pokojarzyć" [PO_PO_06]. Problem tkwi jedynie w tym, iż przekonanie, wyrażone w powyższym cytacie wziętym z wypowiedzi jednej z osób pracujących w Gminnym Ośrodku Kultury w Połajewie, nie do końca ma

9 Reportaż telewizyjny: http://www.tvn24.pl/poznan,43/korowod-ciot-przeszedl-przez-polajewo,310935.html; reportaż radiowy: http://www.radiomerkury.pl/informacje/pozostale/ cioty-w-polajewie.html.

10 Odnośnik do strony wydarzenia na oficjalnej stronie Roku Kolberga: http://www.kolberg2014. org.pl/pl/2014/wydarzenia/iv-zlot-ciot-polajewskich. 
swoje odzwierciedlenie w rzeczywistości. Jeżeli weźmiemy pod uwagę, iż faktycznym niematerialnym dziedzictwem Połajewa jest popularność praktyk para-magicznych lub żywotność legend dotyczących ciot, to zwyczaj dorocznego wyprawiania im sabatów pod patronatem GOK-u jest już niestety współczesnym kulturowym wynalazkiem. Nie sposób zaprzeczyć, że inicjatywa spotkań czarownic jest w pewnym sensie przedłużeniem ich obecności w codziennym życiu połajewian, jednak nie stanowi elementu dotychczasowej lokalnej tradycji w rozumieniu przedmiotowym - do tej pory cioty, jeżeli w ogóle, spotykały się z dala od instytucji kultury i pozostałych siedzib ludzi.

Podobnie jak w przypadku dudziarzy, mamy tutaj do czynienia z nadaniem dawnym elementom dziedzictwa kulturowego nowych znaczeń. Po pierwsze, samo upowszechnienie się określenia ciota połajewska i jego subwersywne używanie, w kontrze do pierwotnej wersji semantycznej, przestało być pejoratywne, odsłoniło wcale nie tak mroczne oblicze lokalnych czarownic - cioty połajewskie stały się synonimem radosnego święta, wiosny, korowodów, Dnia Kobiet. Po drugie, cząstka tożsamości kulturowej mieszkańców Połajewa, jaką stanowiły czarownice, zaczęła pełnić funkcję dominującą - kiedyś we wsi było zaledwie kilka ciot, które pozostawały w ukryciu, obecnie zaś cioty ujawniają się dobrowolnie, manifestując swoją obecność. Po trzecie, powszechność językowego używania terminu ciota zaczęła rozciągać się również na mężczyzn, którzy tak samo jak ich matki, ciotki, partnerki czy sąsiadki zaczęli być kojarzeni terytorialnie z miejscem bytności ciot i współorganizacją ich wiosennych pochodów (w których sami nota bene uczestniczą). Mamy tu zatem znów do czynienia z użyciem, jak to określił Hobsbawm, starego materiału do budowy tradycji nowego typu. W przeciwieństwie do dudziarzy, którzy „zrodzili się" z fragmentu przeszłości zapisanej w postaci materialnej, współczesne cioty stały się totum pro parte miejsca, jakie zajmowały w przekazach ustnych i codziennym życiu mieszkańców Połajewa. Społeczna transmisja niematerialnego dziedzictwa kulturowego oraz jego wykorzystanie jako instrumentu aktywizującego i animacyjnego, spowodowały nie tylko odrodzenie się treści zapisanych w folklorze słownym, ale również ich wyeksponowanie. 


\section{Niematerialne, ale czy dziedzictwo?}

Tradycja, zgodnie z modelem zaproponowanym przez Szackiego, może być rozumiana w trójnasób: po pierwsze - czynnościowo - odnosi się wtedy do międzypokoleniowego przekazywania dóbr kulturowych (transmisja społeczna); po drugie - przedmiotowo - wskazuje, nie sposób przekazywania tychże dóbr, lecz opisuje, które z nich są przekazywane (dziedzictwo); po trzecie - podmiotowo - dotyczy stosunku danego pokolenia do przeszłości, objawiającego się w zgodzie na dziedziczenie dóbr kulturowych bądź ich odrzucaniu [Szacki 2011: 102]. Opisane w artykule zjawiska kulturowe, mimo iż odnoszą się do tradycji lokalnej (czerpią z dziedzictwa; przekazywane są młodszym generacjom; są modyfikacjami wynikającymi z określonego stosunku do przeszłości), nie stanowią jednak tradycji w ścisłym znaczeniu tego słowa, są raczej pewnymi unowocześnionymi jej wariantami, złożonymi z dość arbitralnie wybranych elementów. Ich nagłe pojawienie się i natychmiastowe utrwalenie, jest efektem zapotrzebowania na zapełnienie luk rozrastających się w dotychczasowej obrzędowości (zanik zwyczajów o charakterze integracyjnym, jak chociażby darcia pierza czy spotkań Kół Gospodyń Wiejskich, a także brak ważnych wydarzeń o charakterze cyklicznych spotkań z twórczością artystyczną). Dlatego też mogą być one traktowane jako emanacje kulturowej inwencji. Proces włączenia spotkań dudziarzy i czarownic w tryb dorocznego kalendarza wydarzeń o charakterze kulturalnym, zasadza się na podobnych do opracowanych przez Hobsbawma [2008: 17] funkcjach tradycji wynalezionej, która:

- integruje społeczność i wzmacnia jej poczucie przynależności do grupy ją kultywującej (cykliczne obchody Sabatów i Spotkań Dudziarskich);

- legitymizuje sposób jej przekazu, uznając pewne instytucje jako jej nośniki (działalność Gminnego Ośrodka Kultury i lokalnych animatorów), a wytwory kultury, na których się zasadza, jako teksty dla niej kanoniczne (przekazy ustne dotyczące ciot oraz tryptyk Pokłon Pasterzy);

- ustala pewne normy jej praktykowania oraz wartości i znaczenia im odpowiadające (reinterpretacja tradycji dawnej, jej uwspółcześnienie, performatywny charakter jej odtwarzania). 
Jak słusznie zauważyła jedna z wcześniej już cytowanych mieszkanek Połajewa, jeśli posiada się jakąkolwiek formę uznawanego kolektywnie dziedzictwa, pewnego kapitału kulturowego, który można wykorzystać w celu ożywienia kultury tradycyjnej, to dlaczego tego nie zrobić [PO_PO_06]? Tym bardziej, że powodzenie jednego przedsięwzięcia udowadnia sensowność tworzenia kolejnych, co więcej - wychodzi naprzeciw oczekiwaniom społecznym. Z tego punktu widzenia, najważniejszym aspektem tradycji okazuje się chęć jej transmisji i aktualizacji, wola dziedziczenia, jak by to ujął Stanisław Ossowski [1966: 81-82]. Międzygeneracyjny przekaz dziedzictwa, które zdaniem Szackiego [2011] oznacza nie tyle zbiór elementów materialnych, co przede wszystkim wartości i wzory postępowania, pozwala na zachowanie ciągłości dawnych tradycji, ale równocześnie ich ewolucję. Istota przekazu tkwi w tym, iż każde pokolenie posiada możliwość dokonywania sądów na temat tego, co otrzymuje w spadku po swoich przodkach lub czym jest obarczane. Przejmowane treści kulturowe mogą zostać uznane zarówno za istotne, jak i za warte zapomnienia jako anachroniczne lub nieużyteczne. Wartościowanie dziedzictwa (czy przeszłości w ogóle), różne dla poszczególnych grup pokoleniowych, może wpływać na tworzenie się lub zmniejszanie dystansu pokoleniowego, hamując bądź pobudzając komunikację międzygeneracyjną [zob. Mead 2000], a tym samym przekaz niematerialnego dziedzictwa.

W przypadku poruszanych w artykule przykładów istotne jest podkreślenie, że w proces transmisji pokoleniowej zaangażowane zostały podmioty profesjonalne, a oddolny przekaz ustny zastąpiony został przez odgórną inicjatywę konwersji treści kulturowych w tradycję-markę, użyteczną z punktu widzenia instytucji kultury. Niemniej jednak oba omawiane przykłady, mimo iż posiadają charakter tradycji wynalezionych, pełnią ważne funkcje dla społeczności lokalnej, która przystała na ich podtrzymywanie w zaproponowanej przez animatorów formie. Żeby ocenić stopień odniesienia nowych połajewskich tradycji do pierwotnego wzorca, jakim jest lokalne dziedzictwo kulturowe, trzeba krytycznie spojrzeć na ich wzajemne podobieństwa. W obu przypadkach: 
- mamy do czynienia z pewnego rodzaju kulturowym recyklingiem, który zakłada wykorzystywanie tradycyjnych treści kulturowych do powoływania nowych zwyczajów;

- zwyczaje te są spontaniczną i swobodną reinterpretacją bądź wariacją na temat przeszłych treści kulturowych, z których się wywodzą;

- istotną rolę dla ich powstania i trwania pełni nośnik tradycji, tekst kanoniczny, jak by powiedział Hobsbawm - w przypadku dudziarzy materialny, w przypadku ciot niematerialny;

- inicjatywa wynalezienia nowych tradycji stała po stronie animatorów, co przeczy naturalnemu procesowi oddolnego wykształcania się kultury (ludowej, wiejskiej) $^{11}$;

- ważne miejsce zajmuje przekaz międzypokoleniowy czy też pamięć komunikacyjna - w przypadku dudziarzy podstawą opanowania warsztatu muzycznego jest nauka w relacji mistrz - uczeń; w przypadku ciot połajewskich wymyślane obecnie przysięgi i przyśpiewki odwołują się bezpośrednio do treści lokalnych podań i folkloru słownego, przekazywanych ustnie - z tym jednak zastrzeżeniem, że gdyby nie interwencja animatorów przekaz ten mógłby ulec zatrzymaniu;

- praktykowanie zwyczaju przybiera formę obrzędowego korowodu, któremu towarzyszy rozbudowany folklor muzyczny. Towarzysząca obu wydarzeniom oprawa nosi zatem bardzo widoczne znamiona folkloryzmu, którego celem jest wyeksponowanie elementów artystycznych - w trakcie widowisk, koncertów, przeglądów kapel - oraz celowe estetyzowanie wydarzenia w celu wykreowania pozoru jego autentyczności - użycie strojów ludowych stworzonych na potrzebę Spotkań Dudziarzy oraz przebrań czarownic uszytych na podstawie wzorów zapożyczonych [Burszta 1987: 125-127].

Jakkolwiek odpowiedź na postawione w tytule artykułu pytanie nie jest łatwa, należy, w pewnej przynajmniej mierze, zgodzić się z cytowanym już wcześniej Hobsbawmem: „Tam, gdzie dawne zwyczaje są wciąż żywe, tradycje nie muszą być ani ożywiane, ani wymyślane" [2008: 16]. Trzeba

11 Z tą jedynie różnicą, że animatorka i pomysłodawczyni Sabatu Ciot Połajewskich wywodzi się z lokalnej społeczności, natomiast inicjatorzy spotkań dudziarzy są poznaniakami. 
jednak zauważyć, że w przypadku opisywanych przykładów, wynalazkiem kulturowym jest nie sama tradycja w rozumieniu przedmiotowym (dziedzictwo), ale jej znaczenie i forma jej dziedziczenia (transmisja społeczna). Dawne treści kulturowe, tracąc swoje pierwotne funkcje, zostały odtworzone poprzez nadanie im funkcji zupełnie nowych, aktualnych, użytecznych, atrakcyjnych. Kwestią zasługującą na podkreślenie jest to, że obu tradycjom wynalezionym oddolnie przypisuje się bardzo ważne znaczenie, ponieważ wynikają z bezpośredniego odniesienia do uznanych społecznie elementów dziedzictwa - obrazu i opowieści. Tradycje te, ożywione poprzez działania animacyjne, stały się przedłużeniem lokalnego dziedzictwa, zostały potraktowane przez mieszkańców Połajewa tak, jakby były dziedzictwem samym w sobie. Warte są zatem nie tylko dalszego kultywowania, ale również podjęcia ich badania i ochrony. Przede wszystkim dlatego, że są to tradycje nowe i dynamiczne. Ich dalsza obserwacja może w przyszłości dostarczyć odpowiedzi na pytanie: kiedy zwyczaj staje się zwyczajem, a dziedzictwo dziedzictwem?

\section{Bibliografia}

\section{Burszta Józef}

1987: Folkloryzm. [W:] Słownik etnologiczny. Terminy ogólne. Red. Z. Staszczak. Warszawa-Poznań, s. 131-133.

\section{Drożdż Anna}

2013: Kołysanie diabła - zwyczaje wierzeniowe jako przykład niematerialnego dziedzictwa kulturowego. „Nauka”, nr 1, s. 129-148.

\section{Garstecki Bogdan}

2010: Moje Połajewo. Połajewo: ARCAN.

\section{Hobsbawm Eric}

2008: Wprowadzenie. Wynajdowanie tradycji. [W:] Tradycja wynaleziona. Red. E. Hobsbawm, T. Ranger. Przeł. M. Godyń, F. Godyń. Kraków, s. 9-26.

\section{Jasiewicz Zbigniew}

1967: Czary. [W:] Kultura ludowa Wielkopolski. T. 3. Red. J. Burszta. Poznań, s. $457-486$. 


\section{Łysiak Wojciech}

1992: Mnisia Góra. Podania i bajki warciańsko-noteckiego międzyrzecza. Międzychód: Wydawnictwo ECO.

\section{Mead Margaret}

2000: Kultura i tożsamość. Studium dystansu międzypokoleniowego. Przeł. J. Hołówka. Warszawa: Wydawnictwo PWN.

\section{Ossowski Stanisław}

1966: Dzieła. T. 2. Więź społeczna i dziedzictwo krwi. Warszawa: Wydawnictwo PWN.

\section{Pawlak Aleksander, Pawlak Danuta}

1967: Czary. [W:] Kultura ludowa Wielkopolski. T. 3. Red. J. Burszta. Poznań, s. 269-298.

\section{Rybarczyk Katarzyna}

2013: Współczesny obraz niematerialnego dziedzictwa kulturowego wsi wielkopolskiej na przykładzie gminy Połajewo (pow. czarnkowsko-trzcianecki). Praca magisterska napisana pod kierunkiem dr A.W. Brzezińskiej. Archiwum Instytutu Etnologii i Antropologii Kulturowej Uniwersytetu im.

\section{Szacki Jerzy}

2011: Tradycja. Warszawa: Wydawnictwo Uniwersytetu Warszawskiego.

\section{Zadrożyńska Anna}

1985: Powtarzać czas początku. Warszawa: Wydawnictwo Spółdzielcze.

2002: Świętowania polskie. Warszawa: Wydawnictwo Książkowe Twój Styl.

\section{Strony internetowe}

www.kolberg2014.org.pl/pl/2014/wydarzenia/iv-zlot-ciot-polajewskich [ostatni dostęp: czerwiec 2015].

www.polajewo.pl [ostatni dostęp: czerwiec 2015].

www.radiomerkury.pl/informacje/pozostale/cioty-w-polajewie.html [ostatni dostęp: czerwiec 2015].

www.tvn24.pl/poznan,43/korowod-ciot-przeszedl-przez-polajewo,310935.html [ostatni dostęp: czerwiec 2015]. 


\section{Spis fotografii}

Fot. 1 Pokłon Pasterzy. Renesansowy tryptyk autorstwa Mateusza Kossiora w kościele św. Michała Archanioła w Połajewie; archiwum Gminnego Ośrodka Kultury w Połajewie.

Fot. 2 Dudziarz na renesansowym tryptyku autorstwa Mateusza Kossiora; fot. K. Rybarczyk.

Fot. 3 Zespół dudziarski pod tryptykiem w kościele św. Michała Archanioła w Połajewie; archiwum Gminnego Ośrodka Kultury w Połajewie.

Fot. 4 XIV Spotkanie Kolędników-Dudziarzy w Połajewie, styczeń 2014 roku; archiwum Gminnego Ośrodka Kultury w Połajewie.

Fot. 5 I Sabat Ciot Połajewskich, marzec 2010; archiwum Gminnego Ośrodka Kultury w Połajewie.

Fot. 6 III Sabat Ciot Połajewskich, marzec 2013; archiwum Gminnego Ośrodka Kultury w Połajewie. 


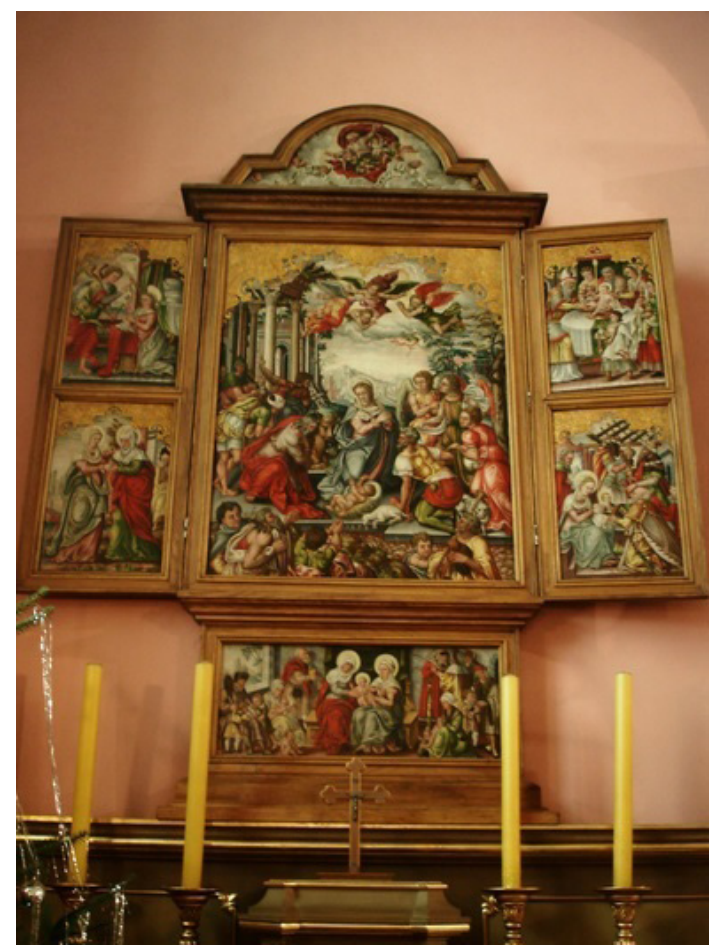

Fot. 1 Pokłon Pasterzy. Renesansowy tryptyk autorstwa Mateusza Kossiora w kościele św. Michała Archanioła w Połajewie

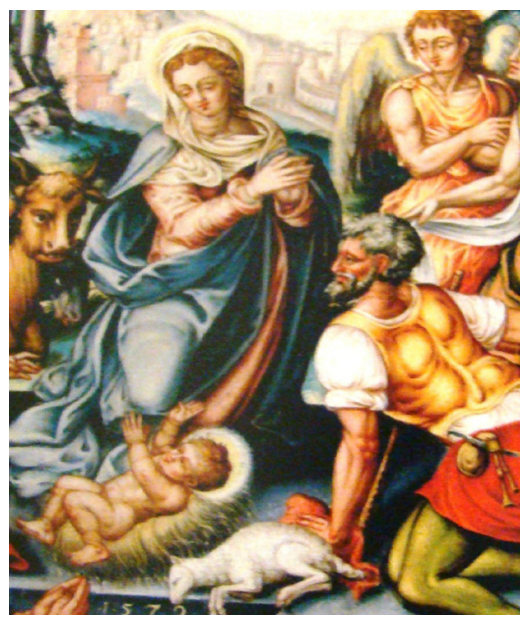

Fot. 2 Dudziarz na renesansowym tryptyku autorstwa Mateusza Kossiora 


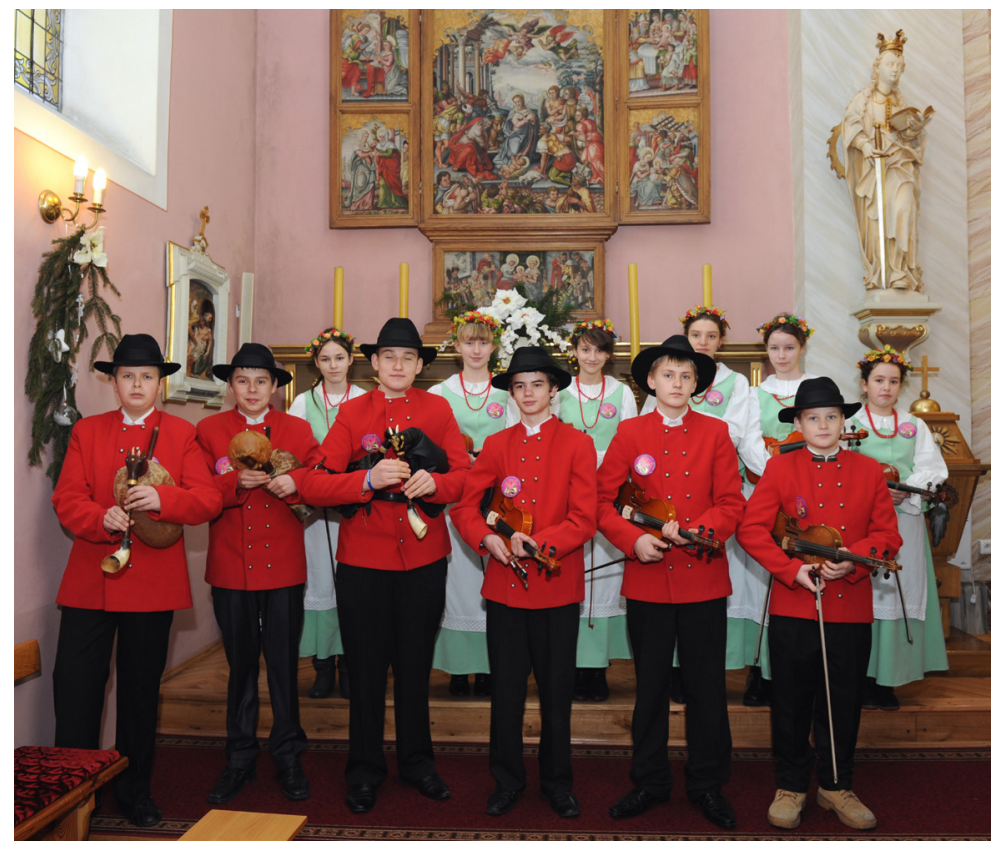

Fot. 3 Zespół dudziarski pod tryptykiem w kościele św. Michała Archanioła w Połajewie

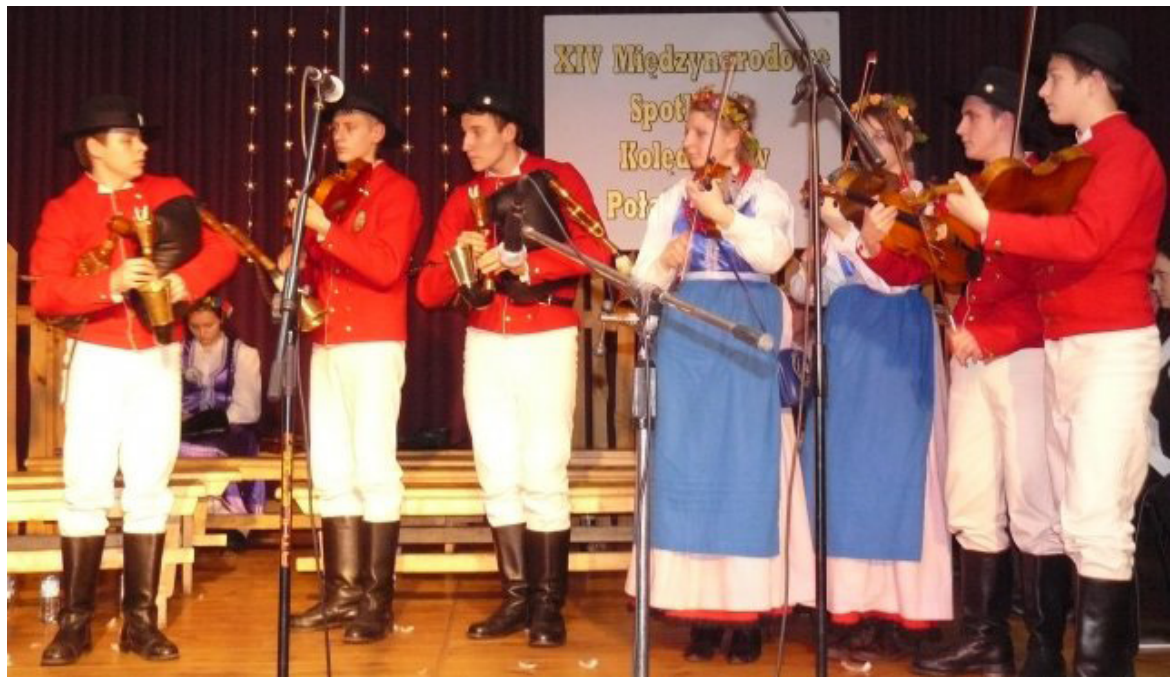

Fot. 4 XIV Spotkanie Kolędników-Dudziarzy w Połajewie 


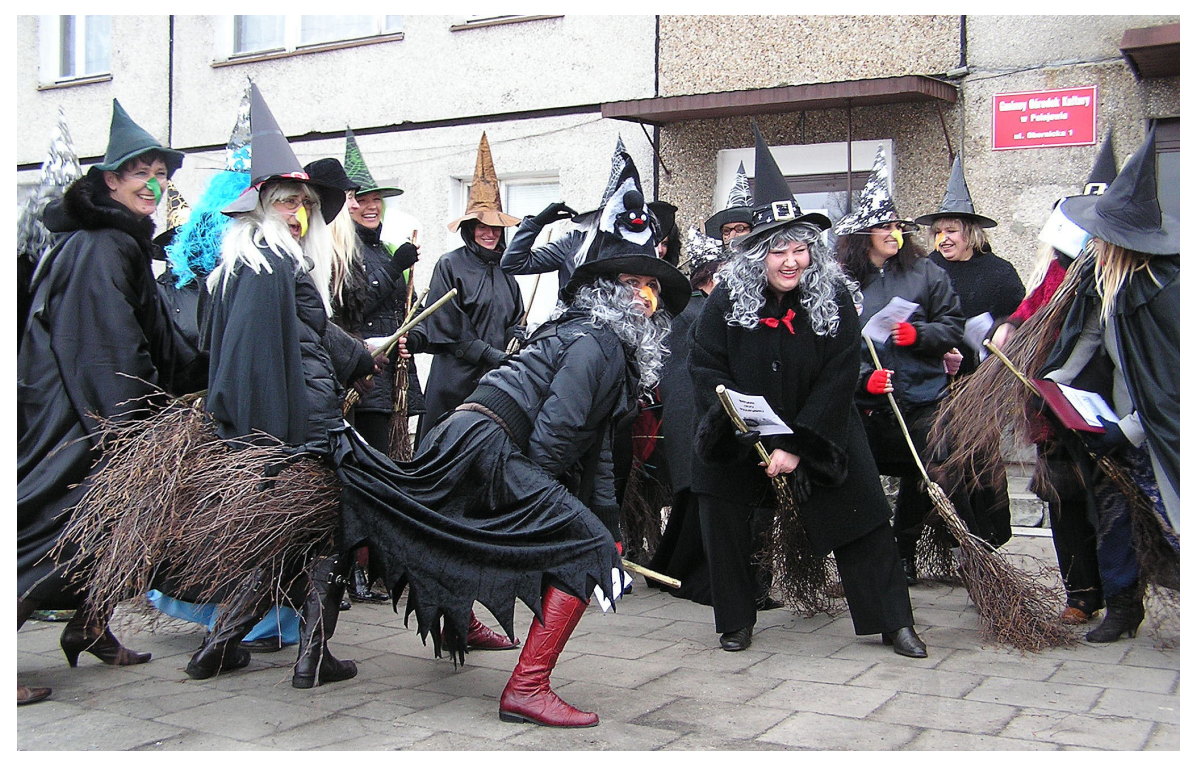

Fot. 5 I Sabat Ciot Połajewskich

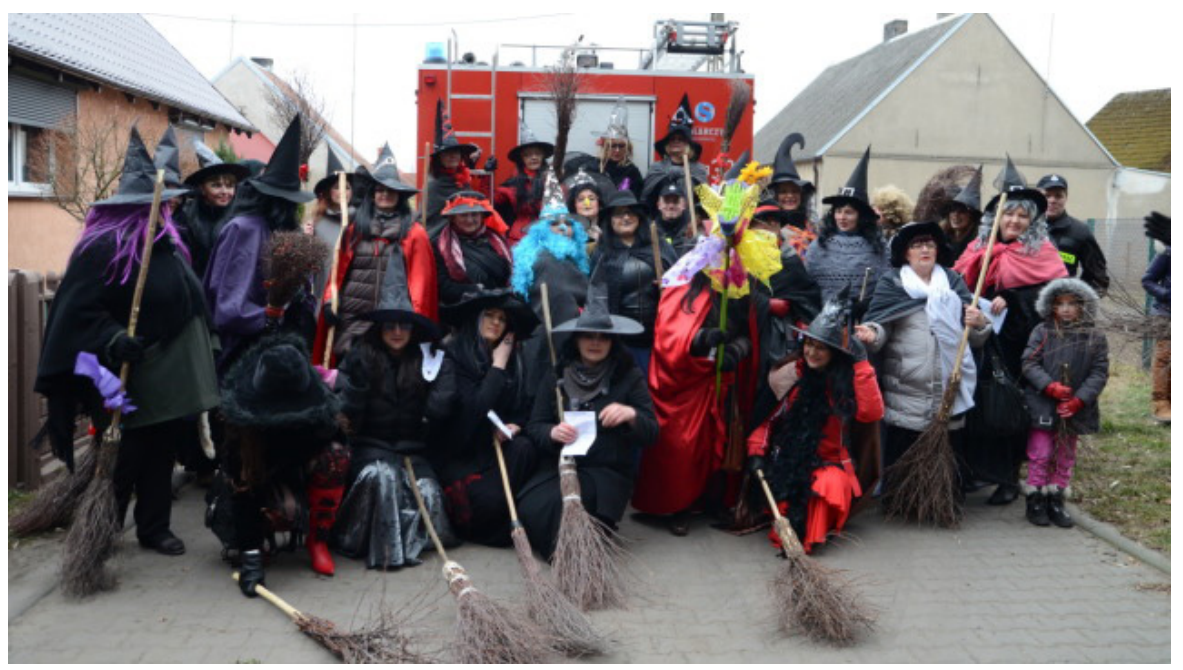

Fot. 6 III Sabat Ciot Połajewskich 